\title{
The Occult among the Aborigines of South America? Some Remarks on Race, Coloniality, and the West in the Study of Esotericism
}

\author{
Mariano Villalba
}

In recent discussions about its global dimensions, esotericism is conceived as a "Western European" phenomenon "spread" or "diffused" from Western Europe to the rest of the world. This can be seen in Wouter Hanegraaff's notion of a "globalization" of esotericism, by which "originally European esoteric or occultist ideas and practices have now spread all over the globe" (2015, p. 86); in Henrik Bogdan and Gordan Djurdjevic's proposal to understand how "occultism changes when it 'spreads' to new environments" (2013, p. 5); in Granholm's statement that "often 'Western culture' is used to denote a 'European culture', which has spread beyond Europe" (2013, p. 18); or in Juan Pablo Bubello's perspective on esotericism in Latin America that presents the idea of a "diffusion of Western-European esotericism in the New Continent in the sixteenth-nineteenth centuries" (2017, p. 39).

In contrast, I argue that esotericism is not a Western European phenomenon spread to the New Continent, as it did not originate exclusively in Europe. Rather, its emergence can only be fully comprehended in light of the conquest of America. While the scope of this article can hardly suffice to fully elaborate this argument, I provide examples from the conquest of the Anáhuac, later known as Mexico, shedding new light on both the nature of the phenomenon and the historical context of its emergence. In the first part of this article, I show how aborigines educated in Castilian institutions produced modern esoteric discourses grounded in Platonism to resist the colonization of their past and integrate it in a European historiography of salvation. In doing so I briefly describe the result of this in modern Mexico, what I term a racial prisca theologia in the cultural movement known as the "Mexican Renaissance" (1920-1925).

Second, I show how the aforementioned diffusionist perspectives are grounded in a misleading Eurocentric premise, making it difficult to address these issues in a productive manner. By denying the Iberian modernity and isolating Europe from its colonial context, this practice conceives modernity (and esotericism) as an exclusive intra-European phenomenon (that would later spread), giving no role to non-European "others," and most importantly to the Iberian Peninsula, in its constitution. Further exploring the context of its 
emergence, I highlight overlooked currents and factors in the Spanish Renaissance and show how this Eurocentric perspective is the main obstacle for correctly identifying the West.

Third, I propose, as a remedy, a decolonial approach that moves from isolated and teleological frames and understands modernity as a phenomenon that emerged in the 1500 s through the Conquest. From this perspective, I provide, on one hand, a clear and historically informed definition of the West and, on the other, discuss race as the central category of modernity that legitimized the new relationships of domination that implanted the caste system in America. Finally, I discuss Martinism in Argentina by way of Henri Girgois' L'occulte chez les aborigènes de l'Amérique du Sud (1897, "The Occult Among the Aborigines of South America"), to show how race and colonialism operate and how this new perspective can be useful.

The "Occult" among the Aborigines of "South America"?

According to Serge Gruzinski (2017, p. 16), renowned Latin America specialist and pioneer of global history, the Conquest of Mexico constituted the foundation of the European historical consciousness, and the globalization of history started with the Spanish and Portuguese colonial expansions. Gruzinski shows that there was not a world history in an empirical sense until Spaniards started writing the histories of aborigines in the Americas. Prior to 1492, the planet was polycentric. Different civilizations coexisted with different ways of recording their past and conceptualizing their territory. However, all civilizations were at the center of their own origin stories. In 1492, for the first time, Europeans insisted that their story was the planetary center, and desired to homogenize the world according to its image. As Gruzinski explains (2017, p. 16), the historization of Amerindian cultures implied both the creation of a historical time and the imposition of it as a universal notion on other civilizations, a process that has not stopped since then.

When examining this issue, Walter Mignolo (1995; 1992) considers the underlying philosophy and civilizing ideology of this historiographical enterprise, by way of the introduction of Western literacy and the book as warranty of "historical truth." The Mexicas recorded their past not with "letters" but paintings (a function occupied by a "specialist," the tlacuilo) and with the "word of the elders," not the "word of the book." Oral transmission of knowledge was considered to be more important than written communication, being deposited in the living body rather than in the book or the letter. The word Tlatollótl, for example, meant "word-memory" or "discourse- 
memory," whose function was to preserve and transmit the memory of the past.

Mignolo (1992, p. 303; 1995, p. 80) remarks that European "philosophers" and "men of letters" (notions alien to the Mexicas) inverted the supremacy of the oral set forth in Plato's Phaedrus, thereby disqualifying the relevance of Amerindian non-alphabetic writings. Writing the correct history of peoples without letters or history of salvation was then a way to colonize their past, thought to be told in a thoroughly irrational manner. Moreover, the writing of thousands of grammars of Amerindian languages resulted in the colonization of their oral languages and the taming of the voice: "when the word was detached from its oral source (the body), it became attached to the invisible body and the silent voice of God, which cannot be heard but can be read in the Holy Book" (Mignolo, 1995, p. 82).

However, this enterprise did not proceed as smoothly as expected. Aboriginal historians began to negotiate the conflict between the forces of their own past and the rhetorical education they received in Castilian institutions (in Latin, Castilian, and Náhuatl), both in the content of their memories and the way of remembering them. Whereas Franciscans, preoccupied with evangelization, tried to link those memories to European religious figures, aboriginal and mestizo intellectuals found in "pagan" figures like Ovid or Homer the references to write their own histories.

Gruzinski (2017, p. 160) calls this process a "secularization of memory," as aborigines started "secularizing" their own memories when writing their codex, erasing all of their past that the Franciscans saw as "religion" and considered as "idolatries." Platonism functioned as a bridge between these oral memories considered as idolatries and Renaissance Hermeticism as "true ancient religion," appropriated by aborigines to resist the said imposition and integrate themselves into Christian historiography (Gruzinski and Bernand, 1992, p. 111). Natives went further and equated their own "pagan" divinities to the "religious" ones, presenting them as potentially superior. Quetzalcóatl, the main Nahua divinity, was equated to Moses or Thomas the Apostle, euhemerized by both Spaniards and aborigines, and was presented as a historical king of the Toltecs who had potentially Christianized those lands prior to the arrival of the Spaniards.

Among the most significant representatives in Peru is Inca Garcilaso de la Vega (1539-1616), son of a Spanish captain and an Inca princess and translator of Leon Hebreo's Dialoghi d'amore (1503). Defending the Incas from "idolatry," Garcilaso proposed an Andean utopia and a common redemption based on a cabalistic interpretation of the Incas' language, the "sacred science" that Plato had learned in Egypt (Bernand, 2006). Other similar cases in New Spain 
include the mestizo historians Fernando de Alva Ixtlilxóchitl (1568-1648) and Diego Muñoz Camargo (1529-1599), who evoked "Divine Plato" and the "ancient discourse of the wise" to write the history of their own nobilities, Texcoco and Tlaxcala, respectively (Gruzinski, 2010, p. 232); Francisco Hernández de Toledo (1514-1587), who advocated the "science of cabala" to explain the common origin of creation between the two worlds (Varey, Chabrán and Weiner, 2000, p. 178); there are also the numerous informers and readers of Athanasius Kircher, for example, Carlos de Sigüenza y Góngora (1645-1700), astrologer and director of the Mexican Academy, the treatises on alchemy of the sixteenth and seventeenth centuries or the unprecedented cases of Hermetic women, the poets Sor Juana Inés de la Cruz (1648-1695) and Sor Ana de Zayas (Trabulse, 1998, 1994).

These productions must be understood in the context of the aborigines' varied acts of resistance to the colonization of their memories and their efforts to relativize cultural differences in European historiography. The crucial aspect is that Latin and Castilian were still considered languages of Enlightenment and religion, and Hebrew the oldest language implanted by God, to which Náhuatl or Quechua could not be really compared. Although aborigines attempted to mark a difference when transmitting their past, by adopting the colonizer's language and historiography they only contributed to the penetration of Occidentalism and the negation of their own traditions (Gruzinski, 2017, p. 37). This tension can be illustrated with reference to Ixtlilxóchitl and Juan Bautista Pomar (1535-1601), two aboriginal historians writing in Castilian the history of Texcoco, the first favorable to Platonism and local memories and the second to Western literacy and historiography.

To learn about the past of New Spain, Ixtlilxóchitl used as sources of information ancient painted historical records and oral testimonies of the elders, that were in tension with Western literacy and historiography:

The philosophers and wise men among them [the nobility of Texcoco] were entrusted with painting all the knowledge they possessed and had attained, and with teaching from memory all the chants they observed in their histories and lore; all of which time altered with the fall of the kings and the lords. (Mignolo, 1995, p. 95)

By means of Platonism, and despite writing in Castilian, Ixtlilxóchitl attempted to integrate into Christian historiography both the content and way of remembering the oral and painted memories. Ignoring this colonial context, Hanegraaff reduces Ixtlilxóchitl's mention of the "Divine Plato" to a "positive appreciation" of "non-Western beliefs": 
Some degree of positive appreciation for non-Western beliefs and practices was possible in so far as they were somewhat reminiscent of monotheist religion; for instance, the Renaissance model of a prisca theologia, based upon a positive idea of "pagan wisdom," could be used as an interpretative grid or "intellectual filter," as when Fernando de Alva Ixtlilxochitl described the ruler Nezahualcoyotl (1402-1472) as "a sage even wiser than the divine Plato, who alone has managed to raise himself up to the knowledge of a single "creator of visible and invisible things." (2015, p. 65)

On the contrary, Ixtlilxóchitl's mention of divine Plato should be read as a way of building a legitimate genealogy of his own nobility according to Western historiographical conventions, based in the orally transmitted past recorded by the tlacuilos. This discourse was known as huehuetlatolli, "the ancient discourse-memory delivered by the elders," used to refer to the wisdom upon which social behavior was regulated and the younger generation educated, equivalent to Western philosophy (Mignolo, 1995, p. 143). By arguing that Nezahualcóyotl preceded divine Plato in this wisdom, Ixtlilxóchitl could construct a pre-idolatrous past and autonomous origin of the religious revelation in his own nobility.

In the opposite case, Juan Bautista Pomar celebrated the cultural achievements attained by the Texcoco nobility through the adoption of Western literacy, and the colonization of previous forms of transmitting the past and knowledge:

It is clear that if they [the nobility of Texcoco] had possessed letters, they would have come to grasp many natural secrets; but as paintings are little capable of retaining in them the memory of the things painted, they did not advance, because almost as soon as the one who had made the most progress died, his knowledge died with him. (Mignolo, 1995, p. 45)

Gruzinski (2017, p. 152) calls this phenomenon an aboriginal "Renaissance," the emergence of a European historical consciousness and the construction of their own transitions from "barbarism" to "civilization" integrating their own repressed past. This "Renaissance" in colonial Mexico took the form of a racial prisca theologia in the "Mexican Renaissance" (1920-1925), the most famous expression of which is the movement of Mexican painters. Mexican intellectuals imagined this past in an older and, thus, superior New World antiquity or "Ancient Mexico" in respect to the European one. The aspiration, still crystallized in the National University of Mexico's motto, “Through my race the 
spirit will speak" (1921), was to invert Hegel's philosophy of history, in which the "spirit" (Geist) originated in China and moved to India, Persia, Egypt, and Greece until "the Germanic spirit (germanische Geist) is the spirit of the New World (neuen Welt)" (Dussel, 1995, p. 23).

The Mexican model of prisca theologia was based, like its European counterpart, upon the idea of a "pagan wisdom" potentially superior to Christianity coming from (the New World's) antiquity: beginning with its founder, Quetzalcóatl, a figure older than Hermes Trismegistus, followed by Buddha (Hegel's origin of the "spirit" moving in a second phase), Plato (European "classical" antiquity), and Bartolomé de las Casas (Spain) as the inaugural moment of modernity. If Hermes was euhemerized in late antiquity and revalorized in the European Renaissance as the potential restorer of "true ancient religion," Quetzalcóatl was euhemerized in colonial America and revalorized in the Mexican Renaissance as the potential founder of a truly New World (Villalba, 2019).

\section{Diffusionist Perspectives and Eurocentrism}

The sequence of world history from Greece to Germany/modern Europe is grounded in Hegel's Philosophy of History. The main agent of history, spirit, moved from "East" to "West" with Asia as a European prehistory and America as a likely candidate to overcome previous forms of history. What Mexican intellectuals attempted in this scenario was to render this "oriental origin" of spirit as older and place it not in Asia but in a "further orient," the "New World." As we now know, the aspiration to render Latin America a superior civilization and culmination of world history failed. For our purposes, this shows that the sequence "Ancient Greece"-Rome-Christianity-modern Europe is an ideological construct only designed, as Hanegraaff $(2015$, p. 85$)$ noted, to present those that control it (or attempt to) as superior and the very summit of world history itself.

Dussel $(2000 ; 1998 ; 1995)$ and Bernal $(1987)$ showed how this was an ideological construct of eighteenth-century German romantics, a discourse about modernity's own origins that appropriated Greek culture as exclusively Western European and posited both the Greek and Roman cultures as the center of world history. Thus, modernity was presented as a selfsufficient, auto-realization of Europe, made possible by its own rationality without any contact with other cultures, and the conquest of "America" as an Entdeckung ("discovery"). This Eurocentric version of modernity is a Kantian "way out" (Ausgang) that usually runs from Italy (fifteenth century), Germany (sixteenth-eighteenth century), England (seventeenth century) to 
France (eighteenth century) and would later "diffuse" to the rest of the world. It is important to understand that Eurocentrism does not simply mean placing Europe in the center but placing a certain Europe in the center while excluding a supposedly peripheral one. In this canonical version, 1492 and the Spanish and Portuguese colonial expansions are considered as having nothing to do with modernity but rather with the end of the Middle Ages.

Gruzinski (2008, p. 54) and Bernand (2009, p. 111) consider the denial of the Iberian modernity as Eurocentric and argue that modernity did not start exclusively in Europe, as other modernities emerged in Colonial America that differed from the canonical Eurocentric one. Dussel (1998, p. 4) and Bhambra (2007) remark upon the academic and ethical problems that this created with regard to non-European "others," whose humanity was negated and who are still considered in predominant sociology as having nothing to do with the constitution of modernity (or esotericism). Dussel shows how Hegel intentionally occluded the Iberian Peninsula and, by extension, the Conquest of America, in canonical narratives of modernity: the "culmination of the spirit" was an auto-realization of Germany, France, Denmark and the Scandinavian countries, "the heart of Europe" (das Herz Europas). This was different from a "Europe from the south of the Pyrenees" where, according to Hegel: "Here one meets the lands of Morocco, Fez, Algeria, Tunis, Tripoli. One can say that this part does not properly belong to Africa, but more to Spain, with which it forms a common basis" $(1995$, p. 26$)$.

In the field of esotericism, this Eurocentrism is most evident when one observes that Spain and Portugal are virtually absent in the Dictionary of Gnosis and Western Esotericism (Hanegraaff, Faivre, van den Broek and Brach, 2005), and several currents are overlooked. For instance, as I indicated elsewhere (2018b; 2016; 2015), Castilian humanist Enrique de Villena (1384-1434) built an "ancient wisdom narrative" and appropriated Jewish kabbalah in the 1420 s and 143os, several years prior to Marsilio Ficino and Pico della Mirandola. Villena pioneered a literature on the evil eye about the powers of "imagination" to cause harm and kabbalistic and astrological practices to prevent this. As unique features of the Spanish and Portuguese Renaissance, this valid object was not observed (Villalba, 2016, p. 37). The alumbrados ("illuminated") movement, initiated by the Erasmist Juan de Valdés (1499-1541) in Guadalajara $\left(1525^{-1559)}\right.$ and also present in New Spain, is not reflected in the Dictionary either (Márquez, 1980).

Although a part of what today is considered Western Europe or "Western culture," the Iberian Peninsula is also excluded from any discussion about the historical context of the emergence of esotericism. For instance, Hanegraaff (2012, p. 5) begins the first chapter of his Esotericism and the Academy with 
the canonical Eurocentric starting point (fifteenth-century Italy) that omits the Iberian modernity: "The history of human thought emerged as a topic of intellectual fascination among Italian humanists in the fifteenth century, and the historiography of what we now call Western esotericism was born along with it." From this perspective, it may seem that the Spanish historiographical enterprise and the philosophical conclusions that took place in the Iberian Peninsula about the nature of the "Indians" had nothing to do with the rest of the polemical historiographies studied and "rejected knowledge" in "Western culture."

This Eurocentrism impedes to observe a relevant factor. Since its imperial expansion at the beginning of the fifteenth century, the Castilian Crown started constructing the historiographical concept of prisci hispani, the origins of the ethnic nation that carried a more glorious past in opposition to Rome. This past was forged by Antonio de Nebrija (1441-1522), author of the first Castilian grammar (1492), who established the origin of Castilian as the language of Enlightenment and religion to unify the territories of the vast imperial Castilian dream together with the expansion of Christianity (Mignolo, 1995, pp. 29-67). The spread of Western literacy and historization of Amerindian cultures produced a discontinuity with the classical tradition, expressed in the tensions between the Renaissance philosophy underlying this historiographical enterprise and the Amerindian resistance to its assimilation based in their own traditions and languages (Gruzinski, 2017; Mignolo, 1995, p. 203; 1992). This historiographical construction and the Conquest, I argue, was a fundamental factor in the emergence of the "ancient wisdom narrative," more precisely, the need to absorb the silence created by the colonization of the Amerindian past and knowledge and to frame Europe's self-colonized past as its own "tradition" (Mignolo, 2011, p. 172). As Hanegraaff concluded, this narrative emerged to integrate the pagan "Other" in some sort of "grammar of encompassment," where it could be constructed "as really 'belonging to us' (that is, Christianity)" (2012, p. 274).

In his article about globalization, Hanegraaff acknowledges that the core of the problem lies in 1492, stating that "when explorers and missionaries arrived in Mexico, Peru [...] they brought their Western models of 'paganism' and 'idolatry' with them." Therefore, esotericism became global when they "discovered that pagan, idolatrous or irrational forms of belief and practice reigned all over the globe" (2015, p. 66). This is an illustration of Dussel and Bhambra's remark, as it neglects that aborigines also "discovered" European culture, making, for instance, Platonic interpretations of their own "idolatry." As Julian Strube (2021, p. 53) rightly points out, Hanegraaff does not engage the relevant literature regarding the aforementioned colonial con- 
texts, resulting in a self-referential line of argumentation and isolating Europe from the power relationships established in colonial expansion. This is why Hanegraaff $(2015$, p. 85) remains firmly in the abstract realm of "mentality" or the intellectual ("positive and negative appreciations," "intellectual filters," a "struggle between the forces of light and darkness," a "dramatic notion of two monolithic 'worlds' or mentalities") and arrives at idiosyncratic conclusions.

According to him, the "way of thinking" of "people in Africa, Japan, India, Latin America, or Antarctica" is based in "participation" and is equivalent to "esotericism" as a "form of thought" (also proposing a cognitive science of religion that would allow us to address this), with rationality as an "anomaly" that "appeared just very recently, in a relatively small part of the world, although it has been spreading like a virus ever since" (2015, pp. 84-86). Quijano (2007), Sousa Santos (2016) and Dussel (1995) remark that techno-scientific rationality is the determining factor in the generation and expansion of European colonialism. Therefore, it is not simply an "anomaly" that "rejected" knowledge exclusively in Europe; it also rejected other forms of life and produced new knowledge outside of Europe, leading, as seen, to a profuse appearance of "esoteric currents" in the Americas.

From the perspective of specialists in native languages and cultures, Hanegraaff's assumption appears misguided and ethnocentric. It is based in an evolutionary technological determinism, according to which the absence of the alphabet would have imposed an insuperable limitation on analytic thought and reflection to other societies (Houston, 2004, p. 32). Mignolo (1995, p. 45) remarks that "writing grammars of Amerindian languages was a complex process with more at stake than just a cognitive issue." Kusch (2010) shows that indigenous thought is also rational, but in accordance with the tributary economic systems in Mesoamerica or the Andes, not a capitalist economy such as that associated with Enlightenment rationality. Gruzinski (2002) described the emergence of what he called the "Mestizo Mind" as a result of the planetary "miscegenation" (métissage), seriously questioning the binary and monolithic oppositions that assume stable and coherent totalities that would condition cognition and behavior. I suggest, then, situating the dichotomies in language and imperial difference, not "cognition" or "mentality."

These aspects should be further explored both in the Iberian Peninsula and in Mexican libraries of the sixteenth century. I will limit this analysis to presenting a decolonial perspective that permits us to better address this vast neglected part of "Western culture," as it moves from isolated and Eurocentric frames and underlines a spatial articulation of power within the Americas. In addition, it offers conceptual tools for understanding race as the central cate- 
gory of modernity that pervades its specific rationality, Eurocentrism, to which esotericism and/or occultism would be no exception.

\section{$3 \quad$ A Decolonial Approach}

The collective known as Modernity/Coloniality (MC) is a group of decolonial thinkers that has been active since the nineties, originating in the aftermath of U.S. programs of "modernization" and installation of military dictatorships in Latin America during the Cold War (Escobar, 2007). These studies focus on the relationships between power and knowledge established during the conquest of America, and hence they are distinguished from postcolonial studies, which are generally dominated by authors coming from former English or French colonies in Asia, Oceania, and the Middle East. Belonging to different geographical origins, imperial interlocutors, and disciplinary boundaries, the two currently hold a productive dialogue. Their differences are outlined by Gurminder Bhambra:

Postcolonialism emerged as an intellectual movement around the ideas of Edward W Said, Homi K Bhabha, and Gayatri C Spivak. While much work in the area of postcolonial studies has directly addressed issues of the material, of the socio-economic, there has also been a tendency for it to remain firmly in the realm of the cultural. In contrast, the modernity/coloniality school emerged from the work of, among others, sociologists Aníbal Quijano and María Lugones, and the philosopher and semiotician Walter W Mignolo. It was strongly linked to world-systems theory from the outset as well as to scholarly work in development and underdevelopment theory and the Frankfurt School critical social theory tradition. (2014, p. 115)

MC's central difference with postcolonial studies was Aníbal Quijano's distinction of "coloniality" from "colonialism." The decolonial concept was formulated at the closing of the Cold War following discussions on decolonization after the Bandung Conference (1955) and struggles for liberation in Asia and Africa. In usual interpretations, colonialism appears to be an issue that occurs outside of Europe, or a by-product of modernity, an unhappy situation that modern visions and ideals would end. Quijano showed that coloniality was the overall dimension of modernity, certainly a European phenomenon, but forged through the emergence of the Atlantic slave triangle and the "modern world-system" in the 15 oos. 
The central thesis of MC is thus that coloniality is constitutive of, and inseparable from modernity; in other words, modernity/coloniality are two sides of the same coin. As Mignolo claims, coloniality is the "hidden side" of modernity and the underlying logic common to all Western colonialisms from the Renaissance to today, even after the end of colonial administrations and processes of decolonization. From one side, the "rhetoric of modernity" tells the triumphant narratives of Western civilization and, from the other, the "logic of coloniality" is the hidden and darker side since the Renaissance and the Enlightenment. Based either on the word of salvation through conversion in the colonial era (1500-1750), salvation by civilization (1750-1945) or modernization (1945-2000) in the contemporary one, the "rhetoric of modernity" marginalizes all other epistemes that do not fit with the principles that aspire to build a "totality of knowledge" where everyone would be included (Mignolo, 2011; Mignolo and Walsh, 2018, pp. 194-210).

\section{Relocating the West in the Study of Esotericism}

Eurocentrism is the reason that there are so many difficulties in delimiting "the West" in the field of esotericism. In his article, "Locating the West," Granholm (2013, p. 22) discusses the appearance of the ideas of "the West" and "Europe," moving from the tripartite division of the world in late antiquity according to the sons of Noah (Japheth/Europe, Ham/Africa, Shem/Asia) to the U.S. formation of NATO in 1949. The missing factor is the addition of "America" to Isidoro de Sevilla's maps and the extension of the old tripartite division of the world in the 150os. When "the Other" came into the picture, it was too late for Noah to have a fourth son; therefore, the "Western Indies" (the name that was synonymous, for three hundred years, with "America") were invented from the very beginning as an extension of Japheth/Europe, as predicted in biblical narratives (Mignolo, 2011, p. 195).

The first fictional East/West division, which later became ontological, began with the Treaty of Tordesillas (1494), when Pope Alexander VI created an imaginary line that divided the Atlantic Ocean from north to south and settled the dispute between Spain and Portugal for the possession of Indias Occidentales, and with the Treaty of Saragosa (1529), which created its respective Indias Orientales among the same emerging empires (Mignolo, 2011, p. 78; Gruzinski, 2010, p. 85; Sousa Santos, 2007, p. 3). The other important but usually ignored fact, is the appearance of "Latin America" as a new geopolitical concept in the middle of the nineteenth century, a crucial piece in the redistribution of power that made Orientalism possible in the second stage of modernity with Eng- 
land and France expanding toward Asia and Africa (Mignolo, 2011, pp. 55-57; 2008).

According to Coronil (1996) and Mignolo (2011), "Occidentalism" or Westernization is not the reverse of Orientalism but its condition of possibility. Occidentalism is "inseparable from Western hegemony not only because as a form of knowledge it expresses Western power, but because it establishes a specific bond between knowledge and power in the West" (Mignolo, 2011, p. 56). What constitutes the West, more than geography or a cultural sphere, is an epistemology constituted by the six modern European imperial languages that since the Renaissance established this bond: in the first phase of modernity, Castilian, Portuguese and Italian, eventually relegated as not well suited for scientific and philosophical discourse in the second phase, when Amsterdam replaced Seville in the management of the "centrality" of the modern world and English, French, and German were posited as the main languages of scientific discourse. Therefore, there is no "Western civilization" before the 150os (Mignolo, 2011, p. 19; 1995, p. 8).

An important aspect for inquiring into the boundaries of "Western" esotericism is then whether there is an "exteriority" to this process of Westernization, largely discussed by Dussel $(2000 ; 1998 ; 1995)$. Beginning with his doctoral research on esotericism in Argentina (2010), Bubello argued that the various autochthonous cultural practices prior to the colonization should be understood as a "cultural other totally alien," but "what is only historizable is the reappropriation/resignification of that universe by the colonizers" (2017, p. 43). I demonstrated that the inverse situation - the appropriation of European culture by aborigines-is not only historizable, but that it is imperative to do so. In no manner should this exteriority or "universe" be considered pure outside, untouched by the modern; rather, it should be considered a negated alterity that is constituted as difference by a hegemonic discourse (Dussel, 1995, p. 66). The crucial aspect is that this negation of humanity is structured in racial terms with the first global racial classification that took place at the beginning of the process of invention of the Western Indies/America.

The words "race" ( $r a z a)$ and "lineage" (linaje) became linked to biological ideas about horse breeding and reproduction in Spain in the first half of the fifteenth century (Greer, Mignolo, and Quilligan, 2008, pp. 75-79). Legal, religious, and racial categories were first structured in Spain with the genealogical notion that Christians who descended from Jewish converts were "New Christians," 
essentially different from "Old Christians" or "Christians by nature," who were considered "clean." The ideological underpinning of those discriminations is most evident in the doctrine and statutes of "blood purity" (limpieza de sangre) that structured the Western Indies' caste system, which argued that Jewish and Muslim blood was inferior to Christian and had no rights to be in the Americas (Mignolo, 2011, pp. 17-19).

According to Quijano (2007, p. 171; 2000), race was the first category of modernity which produced the three "main" social identities that imposed the colonial order in the Indies, "White," "Indian," and "Black," with a sophisticated pyramid of thirty-six new sub-identities regulated by statutes (mestizo, mulato, zambo, criollo, etc.). Race was applied in the first place to the peoples that became Indians, not to the peoples that became blacks, meaning that race appeared much earlier than "color" in the history of the social classification of world populations. In addition, the much older principle of gender domination was encroached upon by the inferior/superior racial classifications in the system. For example, a criolla woman (born in America from Spanish whites) was superior to a mestizo man (born of a Spanish white and an Indian woman); a mestiza woman was superior to a mulato man (born of a white and a black), with the black woman being at the bottom of the pyramid (Quijano, 200o, p. 535).

The first global racial mapping of the world took place at the Valladolid Debate (1550) about the "nature of the Indians" (polémica de los naturales) and the "right of the peoples" (derecho indiano). The orthodox perspective was represented by Juan Ginés de Sepúlveda, for whom reason and religious revelation were not something that natives could find in their own past. In that sense, they were "irrational" and "pagan," thus incapable of accepting religious truth and deserving the conquest by means of violence. His opponent, Bartolomé de las Casas, discussed in his Apologetica Historia Sumaria (1552) the story that attributed the foundation of magic to Zoroaster, to argue that the Indians, like the Europeans, were deceived by the devil when using magic; thus, their religion was not pagan but rational, and therefore compatible with Christian truths, justifying their evangelization and education (1992, p. 709).

Besides inventing "Amerindian religions," Bartolomé de las Casas pioneered our modern idea of humanity, by showing that certain groups of natives potentially had the same rational nature as Europeans, unlike blacks who had no "soul" and were not "human/rational" (Álvarez-Uría, 2015, p. 11). Racism then, does not have to do with one's blood type, or with the color of one's skin, but with the potential of sharing one's genealogy with a European ancestor based on this religious difference (Mignolo, 2011, p. 8). As I will show below, occultists argued that these particular Indian races had indeed arrived 
by their own means to the monotheistic idea of God (according to the Missionaries' conception of a non-European "human/rational" being), but what that proved was the appearance of "occult" phenomena prior to the arrival of the Spaniards.

\section{The Occult among the Aborigines of South America}

Henri Girgois was the first General Delegate of Martinism in South America, and director of the Latin American branch of the Groupe indépendant d'études ésotériques in Buenos Aires. As a French official and medical doctor in the Argentinian army, he participated in the "Conquest of the Desert" (1878-1885), a genocide of aborigines in the Pampas and Patagonia that "brought them to light" and appropriated their lands and resources with the goal of consolidating the nation state. In The Occult Among the Aborigines of South America, aboriginal cultures recently "discovered" are thus presented as a privileged source of knowledge for the esoteric or occult tradition: "the study of the occult in South America was not worth more than one journal article, but new data from new points of view had increased our duty" (Girgois, 1897, p. 5) and "studying seriously the occult tradition in the aborigines means studying all of their main races" (p. 14).

Girgois' study consists of an analysis of what he considers the three "main races" present in the Pampas, the Araucanos, Guaranies, and Quechuas, with a list of their respective "sub races." The nature of the "occult" in the different races depends, in Girgois' study, on their position in the complex social classifications created by the colonial order. As mentioned, "race" was applied first to Indians, and preceded and structured all other social classifications: gender, color of people, and, in this case, the color of "magic" as well. For example, one of the actors that attracted Girgois' attention was the machi, an Indian woman and traditional healer of the Mapuche culture:

Is it not admirable for the thinker to see, in the middle of the desert, the transmission of a centuries-old occult scientific initiation by the savages? Is she not sublime this machi from the Pampas who, captive, surrounded by enemies, not even surrendering to the priests and the threats, does not unveil the secrets acquired by this occult initiation? $(1897$, p. 236)

However, sometimes the machi invoked the Hualicho, a term originally imported by black slaves from Africa, which all the other social actors (whites, criollos, mestizos, etc.) believed to be an evil "spirit" or "demon." In this case, 
the "occult scientific initiation" of the machi not only turned "black" but also could be a part of a counter "black initiation" parallel to the white one:

If we consider the tree consecrated to Hualicho in the island of Guaminí, certainly centuries old, from everywhere in the Pampas come the machis several times a year to repeat their consecrations [...] certain practices of black magic that we can find a little bit everywhere, in the savages or the civilized, the ancients or the moderns, would make believe in a black initiation parallel to the [white] science of the mages. (1897, p. 214)

To thoroughly analyze the historical relationship between race and esotericism, it is useful to observe Girgois' study of Huiracocha, the main Inca divinity. Ultimately, of the three major Indian races residing in the Pampas, the one that kept "the great lines of religion" (1897, p. 87) were the Quechuas. Huiracocha was historically represented by Spanish missionaries with Trinitarian features, with the purpose of demonstrating that, by their "reason" (narrative opened, as seen, by de las Casas), the Quechuas had potentially understood the Christian message prior to the arrival of the Spaniards. Following these narratives, in Girgois' occultist historiography, the Quechuas or Pirhua race originated in Atlantis (in the Atlantic Ocean) and developed "esotericism" (which refers here rather to "initiation") at some stage of the historical development of the Inca civilization prior to the arrival of the Spaniards, when the Quechuas arrived by their own means to the monotheistic understanding of God:

The idea of this supreme God [Huiracocha] had two very different forms: on one hand, a monotheistic idealism, a God pure spirit, capable of incarnating himself in an independent nature and creating himself outside himself; on the other, pantheism, the divination of nature's living forces whose activity is always exercised without being able to raise to the state of a pure spirit, independent from nature [...]. The alteration from HuiraKocha to Illa-Tiksi Huira-Kocha, spiritual light of the abyss, indicates an intellectual progress or a manifestation of the priests' esotericism, when the [Inca] people, by a higher degree of civilization, was capable of understanding something else than symbols. (1897, p. 74)

This decentering of esotericism from either its European or oriental origins took a further step with the second delegate of Martinism in South America, the German occultist Arnold Krumm-Heller (1879-1949), who would take on the name of "Huiracocha." In this case, as I have shown elsewhere (2018a, p. 248), a "Hermetic reaction" can be observed in a South American context, 
which claimed that "Western esotericism" did not originate in Europe, India, or Atlantis, but among the "Ancient Mayas" in America. Julian Strube (2017) has demonstrated how "Western esotericism" is a historical designation developed in the nineteenth century that dissociated India or "the East" from this concept, thus subject to geopolitical reorientations. Precisely, the replacement of Girgois (French military) by Krumm-Heller (German military) in 1908 as head of Martinism coincided with a reorientation in the geopolitics of knowledge in Latin America, represented by the decline of the French intellectual influence and the increasing presence of Germany. Following Marco Pasi's remark, I showed (2018a, p. 247) how Krumm-Heller's understanding of kabbalah played a relevant role in this partition that situated "Latin America" in "Western esotericism." Whereas in 1908, kabbalah had a Jewish origin and was synonymous with "Western esotericism," in 1930, the "true" kabbalah became the "Nordic" one that appeared among the "Ancient Mayas," with the Jewish kabbalah no longer part of "Western esotericism." This conceptualization, therefore, can only be fully grasped in relation to the diverse imperial powers and geopolitical interests, in a more complex way than its adoption as a present academic context might suggest.

\section{7}

\section{Conclusions}

It can be concluded that the absence of the Iberian Peninsula in the Dictionary is not simply a lacuna but rather the expression of a more general occlusion in Eurocentric narratives of modernity. Dussel (1995, p. 18), Sousa Santos (2008, p. 29), Bernand (2009) and Gruzinski (2017) emphasize the need to re-include the Iberian Peninsula, and I argue the same for the field of esotericism. Bringing back potentially occluded currents in Spain and Portugal would represent an important step toward a better understanding of the global dimensions of esotericism and the historical context of its emergence. Future research should consider that these currents were deliberately written out of history by Spanish Enlightened thinkers and modern intellectual proponents of a Catholic Spain, such as Benito Jerónimo Feijoo y Montenegro (1676-1764) or Marcelino Menéndez Pelayo (1856-1912) (Byrne, 2015, p. 11).

I hope to have convinced the reader that esotericism is not simply a Western European phenomenon spread to the rest of the world. Western culture is not synonymous with a European culture that later spread to the rest of the globe, as is commonly assumed in the literature summarized by Granholm (2013, p. 18). Rather, people in the Americas produced, and still produce "Western culture" without being a European culture, such as Inca Garcilaso de la 
Vega, a modern and Western Americano. The West, as I showed, has little to do with a geographical location or a specific culture but rather with a locus of enunciation defined by the European imperial languages. Although not yet acknowledged in the field, modern "esoteric currents" were an integral part of the intellectual discourse of colonial America so that the "globalization of esotericism" was definitely not a "discovery" of "Christian missionaries and explorers" (Hanegraaff, 2015, p. 66). Arguably, it is also not strictly a "Western European" phenomenon- "diffused" to the New Continent, as it has been considered so far (Bubello, 2017) - but global from the outset. Moving from Eurocentric frames and adopting a decolonial or global history approach, one should not be surprised to find indigenous people talking about the Egyptian Hermes or kabbalah in the Spanish Philippines or in any other location of the vast Indies.

The absence of the Iberian Peninsula and the Americas in the Dictionary may also be an important reason why the notion of race which, as I have shown, emerged with the Conquest, is largely absent from current discussions. The present case shows that, when encountering indigenous cultures, modern occultism reproduces hierarchical structures and classifications of race that are constitutive of modernity. In Girgois' occultist historiography, the pirhua race may constitute a "positive Other" (Granholm, 2013, p. 22), but the fact is that this "other" is continually negated, subjected to racial classifications subtended by a religious difference since the narrative pioneered by de las Casas. This allows us to affirm that, if occultism is modern (Pasi, 2009), it is inherently intertwined with colonialism. The "modernity/coloniality of occultism" is most evident in Krumm-Heller's Fraternitas Rosacruciana Antiqua in Latin America, an important chapter of the German politics of racial and cultural expansion (Villalba, 2019, p. 61).

If we continue to assume that esotericism was simply a phenomenon globalized or spread from the West or Europe, this will only contribute to rendering these others invisible. In this sense, we should be conscious not only of the logical or theoretical contradictions of the East/West division but rather of what remains hidden by the geopolitics of knowledge in this division: coloniality. In fact, why was esotericism labeled "Western" in academic discourse, but not "religion," if this is, as Hanegraaff (2016) argued, a tertium comparationis that emerged as result of the crisis of comparison caused by the colonialist expansion and confrontation with "the Other"? Why would esotericism be an exclusively intra-European phenomenon based in the rejection of an exclusively intra-European "Pagan Other"? We conclude by foregrounding the emergence of esotericism through the interaction with a negated Other in America in a constant struggle of power, domination and resistance, aspects that further 
research on colonial America and the Iberian Peninsula can significantly contribute to illuminate.

\section{Bibliography}

Álvarez-Uría, F. (2015) El reconocimiento de la humanidad: España, Portugal y América Latina en la génesis de la modernidad. Madrid: Morata.

Bernal, M. (1987) Black Athena: The Afroasiatic Roots of Classical Civilization, volume 1: The Fabrication of Ancient Greece, 1785-1985. New Brunswick: Rutgers University Press.

Bernand, C. (2006) Un Inca platonicien: Garcilaso de la Vega, 1539-1616. Paris: Fayard.

Bernand, C. (2009) "La marginación de Hispanoamérica por la Historia universal europea (siglos XVIII-XIX)," Co-herencia, 6(11), pp. 107-122.

Bhambra, G.K. (2007) Rethinking Modernity: Postcolonialism and the Sociological Imagination. Basingstoke: Palgrave Macmillan.

Bhambra, G.K. (2014) "Postcolonial and Decolonial Dialogues," Postcolonial Studies, 17(2), pp. 115-121. [Online] DOI: 10.1080/13688790.2014.966414.

Bogdan, H. and Djurdjevic, G. (eds.) (2013) Occultism in Global Perspective. London and New York: Routledge.

Bubello, J.P. (2010) Historia del Esoterismo en Argentina. Buenos Aires: Editorial Biblos.

Bubello, J.P. (2017) "Difusión del esoterismo europeo-occidental en el Nuevo Continente (siglos XVI-Xx)," in Bubello, J.P., Chaves, J.R., and De Mendonca Junior, F. (eds.) Estudios sobre la historia del Esoterismo Occidental en América Latina: Enfoques, aportes, problemas y debates. Buenos Aires: Editorial de la Facultad de Filosofía y Letras, pp. 39-96.

Byrne, S. (2015) Ficino in Spain. Toronto: University of Toronto Press.

Coronil, F. (1996) "Beyond Occidentalism: Toward Nonimperial Geohistorical Categories," Cultural Anthropology, 11, pp. 51-87. [Online] DoI: 10.1525/can.1996.11.1 .02aooozo.

De las Casas, B. (1992) Obras completas 6-8, Apologética historia sumaria. Castelló, V.A. (ed.). Madrid: Alianza Editorial.

Dussel, E. (1995) The Invention of the Americas: Eclipse of "the Other" and the Myth of Modernity. New York: Continuum.

Dussel, E. (1998) "Beyond Eurocentrism: The World-System and the Limits of Modernity," in Jameson, F. and Miyoshi, M. (eds.) The Cultures of Globalization. Durham: Duke University Press, pp. 3-31.

Dussel, E. (2000) "Europe, Modernity, and Eurocentrism," Nepantla: Views from the South, 1.3, pp. 465-478. 
Escobar, A. (2007) "Worlds and Knowledges Otherwise: The Latin American Modernity/Coloniality Research Program," Cultural Studies, 21(2-3), pp. 179-210. [Online] DOI: 10.108 o/o95023806o11625o6.

Girgois, H. (1897) L'occulte chez les aborigènes de l'Amérique du Sud. Paris: Chamuel éditeur.

Granholm, K. (2013) "Locating the West: Problematizing the Western in Western Esotericism and Occultism," in Bogdan, H. and Djurdjevic, G. (eds.) Occultism in Global Perspective. London and New York: Routledge, pp. 17-36.

Greer, M.R., Mignolo, W., and Quilligan, M. (eds.) (2008) Rereading the Black Legend: The Discourses of Religious and Racial Difference in the Renaissance Empires. Chicago: University of Chicago Press.

Gruzinski, S. (2002) The Mestizo Mind: The Intellectual Dynamics of Colonization and Globalization. New York: Routledge.

Gruzinski, S. (2008) Quelle heure est-il là bas ? Amérique et Islam à l'orée des temps modernes. Paris: Éditions du Seuil.

Gruzinski, S. (2010) Las cuatro partes del mundo: Historia de una mundialización. México: Fondo de Cultura Económica.

Gruzinski, S. (2017) La machine à remonter le temps: Quand l'Europe s'est mise à écrire l'histoire du monde. Paris: Fayard.

Gruzinski, S. and Bernand, C. (1992) De la idolatría: Una arqueología de las ciencias religiosas. México: Fondo de Cultura Económica.

Hanegraaff, W.J. (2012) Esotericism and the Academy: Rejected Knowledge in Western Culture. Cambridge: Cambridge University Press.

Hanegraaff, W.J. (2015) “The Globalization of Esotericism," Correspondences, 3, pp. 5591.

Hanegraaff, W.J. (2016) “Reconstructing 'Religion' from the Bottom Up," Numen, 63, pp. 576-6o5.

Hanegraaff, W.J., Faivre, A., Broek, R.v.d., and Brach, J.-P. (eds.) (2005) Dictionary of Gnosis and Western Esotericism. Leiden-Boston: Brill.

Houston, S. (2004) "Literacy among the Pre-Columbian Maya: A Comparative Perspective," in Boone, E.H. and Mignolo, W. (eds.) Writing without Words: Alternative Literacies in Mesoamerica and the Andes. Durham: Duke University Press, pp. 27-49.

Kusch, R. (2010) Indigenous and Popular Thinking in America. Durham: Duke University Press.

Márquez, A. (1980) Los alumbrados: Orígenes y filosofia, 1525-1559. Madrid: Taurus.

Mignolo, W. (1992) "On the Colonization of Amerindian Languages and Memories: Renaissance Theories of Writing and the Discontinuity of the Classical Tradition," Comparative Studies in Society and History, 34(2), pp. 301-330. [Online] DOI: 10.1017/ Soo10417500017709. 
Mignolo, W. (1995) The Darker Side of the Renaissance: Literacy, Territoriality, and Colonization. Ann Arbor: University of Michigan Press.

Mignolo, W. (2008) The Idea of Latin America. Malden: Blackwell.

Mignolo, W. (2011) The Darker Side of Western Modernity: Global Futures, Decolonial options. Durham: Duke University Press.

Mignolo, W. and Walsh, C.E. (2018) On Decoloniality: Concepts, Analytics, and Praxis. Durham and London: Duke University Press.

Pasi, M. (2009) "The Modernity of Occultism: Reflections on some Crucial Aspects," in Hanegraaff, W.J. and Pijnenburg, J. (eds.) Hermes in the Academy. Amsterdam: Amsterdam University Press, pp. 59-75.

Quijano, A. (2000) "Coloniality of Power, Eurocentrism, and Latin America," Nepentla: Views from South, 1(3), pp. 533-80.

Quijano, A. (2007) "Coloniality and Modernity/Rationality," Cultural Studies, 21(2-3), pp. 168-178. [Online] DoI: 10.1080/o9502380601164353.

Santos, B.S. (2007) "Beyond Abyssal Thinking: From Global Lines to Ecologies of Knowledges', Revista Crítica de Ciências Sociais, 78, pp. 3-46.

Santos, B.S. (2008) "A filosofia à venda, a douta ignorância e a aposta de Pascal," Revista Crítica de Ciências Sociais, 8o, pp. 11-43. [Online] Dor: 10.400o/rccs.691.

Santos, B.S. (2016) Epistemologies of the South: Justice against Epistemicide. Abingdon: Routledge.

Strube, J. (2017) "Occultist Identity Formations Between Theosophy and Socialism in fin-de-siècle France," Numen, 64, pp. 568-595.

Strube, J. (2021) “Towards the Study of Esotericism Without the 'Western': Esotericism from the Perspective of a Global Religious History," in Asprem, E. and Strube, J. (eds.) New Approaches to the Study of Esotericism, pp. 45-66.

Trabulse, E. (1994) Ciencia y tecnología en el Nuevo Mundo. México: Colegio de Mexico.

Trabulse, E. (1998) "El tránsito del hermetismo a la ciencia moderna: Alejandro Fabián, sor Juana Inès de la Cruz y Carlos de Sigüenza y Góngora," Calíope: Journal of the Society for Renaissance and Baroque Hispanic Society, 4(1-2), pp. 56-71.

Varey, S., Chabrán, R., and Weiner, D. (2000) Searching for the Secrets of Nature: The Life and Works of Dr. Francisco Hernández. Stanford: Stanford University Press.

Villalba, M. (2015) "El Tratado de Astrología atribuido a Enrique de Villena: Esoterismo en la corte de Juan II de Castilla," Magallánica: Revista de historia moderna, 2(3), pp. 186-216.

Villalba, M. (2016) "Cábala y aojamiento en el Tratado de la Fascinación de Enrique de Villena," Melancolia, 1, pp. 30-5o.

Villalba, M. (2018a) "Arnold Krumm-Heller, la Revolución Mexicana y el esoterismo en América Latina," REHMLAC+, 1O(2), pp. 227-258. [Online] Dor: 10.15517/rehmlac .vıi2.33355. 
Villalba, M. (2018b) "Enrique de Villena," in Burns, W. (ed.) Astrology through History. Interpreting the Stars from Ancient Mesopotamia to the Present. Santa Barbara: ABC-CLIO, pp. 342-343.

Villalba, M. (2019) “Mission de la race ibéro-américaine: Arnold Krumm-Heller et l'Empire allemand pendent la Révolution Mexicaine (1910-1920)," Politica Hermetica, 33. Lausanne: L'Age d'Homme, pp. 51-66. 